\title{
The Effectiveness of Communicative Speaking Activities on EFL UNRWA 9 graders' Motivation from Teachers' Perspectives
}

\author{
Ahmed Naim Hamed Abu Sharkh \\ MA in Linguistics from the IslamicUniversity, Gaza; Lecturer of EFL at Dawa College, IDC, Gaza-Palestine \\ $\triangle$ Corresponding Author: Ahmed Naim Hamed Abu Sharkh, E-mail: abusharekh3@gmail.com
}

\section{ARTICLE INFORMATION ABSTRACT}

Received: December 08, 2020

Accepted: January 14, 2021

Volume: 3

Issue: 1

DOI: $10.32996 /$ ijels.2021.3.1.3

\section{KEYWORDS}

Communicative activities, speaking skill, motivation
The current study attempts to investigate the influence of communicative speaking activities on motivation of the UNRWA 9th graders to learn English as a foreign language (EFL) from teachers 'points of view. Conducting qualitative analysis, the researcher uses semi-structured interviews in order to get data of the study. The 'Behaviorism Theory' by the behaviorist P.F. Skinner is the theoretical framework of the study. Twenty EFL instructors, 10 males and 10 females, participated in the present study from five UNRWA schools in Gaza. The study finds that communicative speaking activities increase learners' motivation to learn EFL especially when the learners engaged effectively in such activities that also, according to the most majority of the interviewees, increase their level of achievement, a solid correlation between communicative speaking activities and the increase of EFL learners' motivation to learn EFL. The researcher recommends adopting various communicative activities, by EFL instructors, to motivate learners to learn EFL through the main four skills, setting up training programs, by $\mathrm{MOE}$, for EFL instructors to train them how to foster learners' motivation through communicative activities and conducting further researches to investigate the impact of communicative listening, reading and/or writing activities on learners` motivation to learn EFL.

\section{Introduction}

Since the ultimate goal of learning English as a foreign language (EFL) in the Palestinian context is to foster students' ability to use the language communicatively, the speaking skill is considered a crucial factor for that purpose. However, it has been noted that most of the Palestinian EFL learners express frustration of speaking difficulties of English language as, beside it is not officially spoken outside classrooms; they lack motivation to master it. Therefore, when learners master speaking skills, they can use the language communicatively so that this leads to foster their impetus to learning English as a foreign language; As a result, it is essential to offer students opportunities inside classrooms to be motivated through communicative speaking activities in order to learn the target language.

At this point, Aggouni (2015) states that motivation is a psychological aspect which is a notion that bring about the actions and has an important role in carrying out any target purpose. Thus, motivation is basically considered an important factor in learning a foreign language because it targets learners' affection that can affect their desire and interest in learning a language. Cheng and Dornyei (2007) as cited in Ochoa et al (2016) state that learners do not motivated sufficiently, no progression will be in the process of mastering proficiency of language; also, high level of motivation will be effective for learners to gain the suitable level of L2 proficiency. So, it is clear that there is a relationship between students' mastery of a foreign language (L2) and the degree of their motivation. The current study tries to crystallize the effectiveness of communicative speaking activities on learners` motivation from the perspectives of EFL instructors in the Palestinian context.

\subsection{Rationale of the Study}

It has been noted that a vast number of the Palestinian students, studying at public schools, UNRWA schools and other academic institutions, from grade 1 to 12 consider English language as a difficult language to learn. They even graduate from

K C AL-KINDI CENTER $\mathbf{R}$ FOR RESEARCH AND $\mathbf{R}$ D DEVELOPMENT Your gateway to world-class research

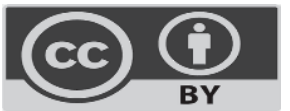

Published by Al-Kindi Center for Research and Development. Copyright (c) the author(s). This open access article is distributed under a Creative Commons Attribution (CC-BY) 4.0 license 
'Tawjihi' with poor English communicative competence due to their negative perspective towards the English language; therefore, their motivation to learn it is low. Thus, this study attempts to investigate whether communicative speaking activities conducted by EFL instructors have an influence on learners to be motivated to learn English language. Hence, the current study highly depends on data of semi- structured interviews of EFL instructors to investigate their own perspectives according to their teaching experience.

\subsection{Statement of the Problem}

Motivation of learners is basically considered vital in the process of learning FL/SL. Thus, it is worthy to be taken into consideration by EFL/ESL researchers, instructors, educational policy makers and others since there is a noticeable gap between students`academic achievement after twelve years of teaching and learning English language and their motivation to learn it. Therefore, with state-of-art approaches to teaching and learning English language; high tendency is paid to communicative language teaching (CLT) that focuses on student-to-teacher interactions and student-to-student interactions. As a result, it is essential to utilize such approaches to promote learners', particularly the Palestinians', motivation to learn the English language. The existing study seeks to find the impact of communicative speaking activities from teachers' perspectives as well as it attempts to find the link between communicative speaking activities and motivation of students.

\subsection{Concepts of the Study}

\subsubsection{Communicative activities}

According to Richards and Rodgers (2001) as cited in Heng (2013) communicative activities can be regarded as exercises in which students involve in communication and help each other to achieve certain goals. Furthermore, Stern (1992) as cited in Ochoa et al (2016) defines communicative activities as exercises in which learners engage in authentic communication.

Thus, in communicative activities, learners interact between each other as in real life situation in order to reach out intended goals. Furthermore, Ochoa et al (2016) state that such activities include language diversities without any intervention of instructors, material control or focusing on forms or meaning.

In addition, Corbett (2003) as cited in Heng (2013) points out that activities students engage in such as information gap, tasks of information transfers are examples of communicative activities.

Oradee (2012) states that communicative activities are these activities which help learners create interaction in the classroom. They can motivate students and build well-satisfied relationships between the instructors and learners and also among students per se. So, the more interaction between students is, the higher level of students` motivation will be.

\subsubsection{Speaking skill}

Speaking is the process of producing and exchanging meaning via the adoption of verbal and non-verbal codes in various contexts. (Chaney, 1998) as cited in (Kayi, 2006). Speaking can also be defined as an interactive process of setting up meaning that includes creating, receiving and processing information. (Burns \& Joyce, 1997) as cited in (Torky,2006; Abu Alyan,2013). In addition, speaking is one of the four main skills through which learners can interact with others to obtain specific purposes to express their ideas, perspectives and point of views. Torky (2006).

\subsection{Motivation}

According to (Lee, Mclnerney, Liemc \& Ortigad, 2010) as cited in (Crajcevci \& Shala, 2017, p.151), "motivation represents an inner state that influences behavior by initiating, directing and maintaining it." Also, according to (Yates, 2004) as cited in (Rashid \& Rana, 2019) motivation is the inner spark that provokes individuals to perform for the sake of satisfying their interests.

\subsection{Purpose of the Study}

The ultimate purpose of the current study is to explore the effectiveness of communicative speaking activities on learners' motivation from both EFL teachers' perspectives. In addition, this study seeks to find new insights about how motivation is perceived by teachers in EFL classrooms.

\section{6. Objectives of the Study}

a. To investigate the impact of communicative speaking activities on learners' motivation from the perspectives of EFL teachers.

b. To investigate the relationship between communicative speaking activities and motivation of learners.

c. 2. To provide the Palestinian EFL teachers new insights about how their learners regard communicative speaking activities. 


\subsection{Questions of the Study}

According to the objectives of the study, the current study seeks to answer the following questions:

a. What is the impact of communicative speaking skills on learners' motivation?

b. What is the connection between communicative speaking activities and learners' motivation?

\section{Literature Review}

Several researches have been implemented to explore the importance of mastering speaking skills, and also a considerable attention is paid to communicative practices that foster learners ' motivation which is considered at the forefront of concern and investigation as learning change is acknowledged. (Çankay,2018).

Speaking is seen as integrated actions of tailoring meaning which is presenting in generating, obtaining and processing information. (Burns \& Joyce, 1997; Lindsay \& Knight, 2006; Richards \& Renandya, 2002) as cited in (Abu Alyan, 2013). This process of creating meaning is as a key element of delivering intended messages, expressing ideas and achieving other communicative purposes.

Pathan, Aldersi and Alsout (2014) believed that speaking skill is perceived as one of the most important skills that enables the student to achieve communication successfully. Therefore, when learners master the speaking skill, they feel that they achieve one of the central aims of learning foreign language. Thus, it is essential to examine the effect of communicative speaking activities on learners" motivation as "students are more likely motivated to learn when what is learned has meaning and influence on their lives." (Johnson, 2017, p.47)

Yulis, Antoni and Rasyidah (2016) conducted a study to examine the link between eight grade learners' motivation and their speaking skill and they found that there is a high level of correlation between them. Therefore; students' motivation can be improved through speaking activities.

Likewise, Badroeni (2018) found in his study that there is a growth in learners' motivation in speaking English by strategies of active learning. All in all, "Motivation is considered a core factor affecting learners' achievement." (Scarcella \& Oxford 1992; Rehman et al., 2014; Mallik 2017) as cited in (Eno, Kumar and Hamza, 2018, p.4).

However, little attention has been paid, in the Palestinian context, to the effectiveness of communicative speaking activities on the Palestinian EFL learners. Several researchers around the globe have conducted many studies in order to investigate the impact of communicative activities on EFL/EFL learners` motivation.

Masmaliyeva (2014) as cites in Ochoa et al (2016) investigated the pros and cons of ELT's speaking presentations in EFL classrooms. His study aimed at analyzing learners' attitude, engagement and mastery of language that resulting from the adoption of oral presentations rather than using a course book in English speaking class for advanced levels. He concluded that learners' motivation is increased through using oral presentations.

Likewise, in a study conducted by Ko, Schallert and Walters (2003) as cites in Wijetunge (2016), it clarifies the impact of question-and-answer technique after a task of a story telling on learners' motivation. As a result, "allowing the students have time to ask and answer questions ( $Q$ and $A$ ) by their peers and teachers... allows them the chance to improve their responsive abilities in the language." (Wijetunge, 2016, P. 205).

Hence, it can be said that motivation of learners to learn FL/SL through communicative speaking skills is connected to teachers' practices to pave the way to students to upgrade their oral skills through selecting the suitable strategies and techniques of teaching and learning that increase their interests, attitudes, and desire to learn the language. Thus, the current study investigates the effectiveness of communicative speaking activities on learners' motivation in the Palestinian context.

\subsection{Theoretical Framework}

It is believed that human beings' behaviors can be conditionally, not in a spontaneous way, learned by triggers of reinforcement (Rewards and Punishments). Likewise, in the process of learning, it is perceived that learning as a set of behaviors can be controlled and modified by those stimuli, and if so, an evidence of learning will be noticed.

The present study is based on the 'Behaviorism Theory' coined by the behaviorist

P.F. Skinner in 1937. Gordan \& Krishanan (2014, p.680) state that "The Reinforcement Theory is one of the oldest theories of motivation which describe behavior and how we act. This theory can be called as 'behaviorism' or 'operant conditioning' that is taught in the today's world of psychology." Additionally, "Behaviorist theory is based on the belief that the language is learned by ' forming good habits through reinforcement." (Thornbury, 2005, P.38) as cited in (Novakova, 2012, P.88).

Also, Staddon \& Ceruttie (2006, P.1) state that "In practice, operant conditioning is the study of reversible behavior maintained 
by reinforcement schedules." They added that in the subsequent decades, Skinner and his colleagues and students encountered a largely unsuspected array of strong and organized scheduled effects that provided new tools to understand learning processes and new phenomena to test theory.

Furthermore, Demirzen $(1988,137)$ illustrates in his book five operating principles for behaviorism. Two of them are connected to the current study:

a. Behaviorist theory is based on spoken language as well as it perceives language as speech and humans begin, from infancy, learning to speak before learning reading and writing. Thus, learning speaking should be at the top priority in language teaching.

b. All learning processing is based on habit formation resulting from reinforcement and rewards (positive and negative), the former is reward whereas the later in punishment.

c. It can be said that in teaching practices, students' behaviors should be taken into consideration in terms of the behaviorist theory that focuses on the psychological factor of learners. Thus, the current study seeks to investigate the impact of communicative speaking activities on learners` motivation.

\section{Methodology and Design}

To analyze data of the study, the present study uses qualitative content method in order to investigate the impact of communicative speaking activities on students' motivation to learn English as a foreign language (EFL) in the Palestinian context from the instructors' perspectives. The instrument uses in this study is semi-structured interviews that allow generating new questions to be answered by the interviewees; meanwhile, a researcher sets up a number of questions sequenced in themes to be investigated. (Lindlof \& Tyor, 2002) as cited in (Abu Alyan, 2013). In addition, all interviews` questions are based on teachers' experience in EFL classes.

\subsection{Participants}

articipants in the current study are 20 EFL instructors, 10 males' and 10 females', from five UNRWA schools, located in the northern area of Gaza. They are interviewed during the first semester of the academic year 2019-2020.

\subsection{Procedures}

The researcher of the current study sets up semi-structured interviews to the participants in order to discuss communicative speaking activities learners are exposed to in the classroom and to investigate the impact of such activities on the learners' motivation. Furthermore, EFL instructors, as participants in the study, are interviewed in order to discuss their point of views towards the impact of such activities. To take permission, the researcher officially sent a written letter to the school principals of the five schools and to the UNRWA district education office to interview the participants. In addition, the researcher met the teachers to explain them the rationale and purpose of the study, provide them briefly some information about the questions of the interviews and specify the suitable time to conduct the interviews. The researcher consulted two applied linguistic researchers from the English Department at the Islamic University in Gaza and two professors lecturing at Al- Azhar University to review the theoretical framework of the study, the research main questions, and the open-ended questions of the semistructured interview.

\subsection{The Instrument}

\subsubsection{Semi-structured Interviews}

These open-ended questions perhaps present fruitful insights into the perception of EFL teachers who are interviewed in the current study. Based on the theoretical background of the current study, six questions are presented to the participants.

a. What is the impact of communicative speaking skills on learners' motivation?

b. Do you prefer teaching speaking skills through communicative activities or just through repetitions and drilling? And why?

c. Do you think that a large number of learners lack motivation to learn English as a foreign language? Why?

d. How do you know whether your students get motivated by communicative speaking activities to learn EFL or not?

e. Is there any connection between communicative speaking activities and learners' motivation?

$\mathrm{f}$. It is said that the Palestinian learners, after 12 years of learning English as a foreign language, lack motivation to learn EFL. If so, how can you as a teacher overcome this problem? 


\section{Results and Interpretations}

\section{What is the impact of communicative speaking activities on learners' motivation?}

Almost all the interviewees indicate positive point of views towards to the influence of communicative speaking activities on learner's motivation to learn EFL. Al Haj (2011) as cited in Ochoa et al (2016) recommends teachers, in his study, to use communicative activities that promote motivation of learners, such as: contests, songs and games, share work, activities of problem-solving, interviews, and role playing.

Salah, who has been teaching English since 2003, believes that when learners are engaged effectively in the communicative speaking activities, their enthusiasm of learning is promoted.

He states that," When I conduct a (role playing activity), I notice that even low-level achievers raise their hand to take permission for participating in the activity and for taking a role to be achieved." So, it is clear that communicative speaking activities influence the learners to be motivated to learn English as a foreign language.

Likewise, Majd, who has an MA degree in language assessment, points out that all types of communicative activities, especially communicative speaking activities, are essential in promoting learners ' motivation. He adds that the main challenge of teaching $\mathrm{EFL}$ is to enable learners express their interests towards the language.

The teacher Majd states that," I always try to encourage my learners to speak English without worrying of committing mistakes. When learners feel that they can speak, their passionate towards English language will increase; therefore, that this passion leads them to learn more skills and sub-skills to keep going forward."

On the other hand, Rania, a teacher of the $8^{\text {th }}$ and $9^{\text {th }}$ grade, has a different perspective towards the impact of communicative speaking activities. She argues that learners cannot be motivated by focusing only on communicative speaking activities. Rania states that there should be a balance among activities that target the main four skills.

She adds, "However, using pictures, role-playing and games in communicative speaking activities can increase learners" motivation to learn English as a foreign language, teachers of English as a foreign language should use various types of activities like drilling and repetition that focus on very important features of speaking, such as pronunciation, intonation and so on."

Thus, it can be noticed EFL teachers have positive perspectives towards the use of communicative speaking activities that have a prominent impact on learners' motivation to learn English as a foreign language. Also, other activities that highlight speaking features should not be ignored.

2. Do you prefer teaching speaking skills through communicative activities or just through repetitions and drilling? And why?

A number of the interviewees prefer teaching speaking skills through communicative activities while others believe that there should be a balance of using both communicative and non-communicative activities.

Bahaa, states that," I always tend to teach speaking skills communicatively because learners benefit from various values, I try to expose my learners to, such as: social interaction, collaboration, and tied relationships. Therefore, my learners become motivated once these values are absorbed."

On the other hand, Nada states that according to teaching goals and objectives, "I use both communicative and noncommunicative speaking activities to foster motivation of my learners to learn EFL. When the teaching objectives focus on teaching fluency, I use communicative speaking activities, but when the focus is on accuracy, I use non-communicative speaking activities."

She added that despite the diversity of learning styles in EFL /EFL classrooms, learners tend to participate more in communicative activities, and I feel they considered such activities as entertainment. Al Haj (2011) as cited in Ochoa et al (2016) found in his study that various types of teaching and learning activities conducted in EFL /EFL classrooms have an important role in motivating learners and paving the way to acquire EFL easily.

\section{Do you think that a large number of learners lack motivation to learn English as a foreign language? Why?}

The process of reinforcing learners` motivation is not easy for English language teachers. Wijetunge (2016). Most of the participants of this study believe that a vast majority of the Palestinian EFL learners lack motivation to learn EFL.

Adam, a freshman teacher, states that, "it is noticeable that the Palestinian EFL learners even do not try to be involved in most of classroom activities, especially speaking activities, due to the lack of interests of English language." He claims that this lack is due to their perspective towards the difficulty of English language, the lack of self-confidence, the fear of committing mistakes, the lack of encouragement and the abstaining of trying. 
Similarly, Salwa, like other professional teachers, believe that the most important thing in classroom practices is to break the ice of shy learners who are not confident to express their needs, interests and wants.

She says," Learners always need a space to be emerged in, to reflect their personality and characters and to speak out without anxiety and fear of losing face." She adds," I believe in all of my learners" ability to speak fluency, when they do so, they will love English language and they will do their best to learn more and more."

Consequently, Salwa's point of view illustrates that learners' motivation is a high priority of teachers' classroom practices to overcome learners' weakness's points that hinder them to learn English language. These obstacles are like shyness, lack of selfconfidence, anxiety, and embarrassment.

"I use both communicative and non-communicative speaking activities to foster motivation of my learners to learn EFL. When the teaching objectives focus on teaching fluency, I use communicative speaking activities, but when the focus is on accuracy, I use non-communicative speaking activities."

She added that despite the diversity of learning styles in EFL /EFL classrooms, learners tend to participate more in communicative activities, and I feel they considered such activities as entertainment. Al Haj (2011) as cited in Ochoa et al (2016) found in his study that various types of teaching and learning activities conducted in EFL /EFL classrooms have an important role in motivating learners and paving the way to acquire EFL easily.

\section{How do you know whether your students get motivated by communicative speaking activities to learn EFL or not?}

Most of the interviewees state their own criteria to judge if their students get motivated to learn English as a foreign language EFL by communicative speaking activities or not.

Salam, a 5-year experience EFL teacher, claims that there are various practices by students indicate that they get motivated to learn EFL.

"There are many indications that obviously indicate growing of my learners' interests and attitudes towards English language. For example, the most majority of students participate less when presenting a new grammatical rule using traditional methods; in contrast, when using communicative activities, especially speaking's, their participation is increasingly noticeable."

In addition, Nahed states that "when my students suggest repeating certain games, songs and/or contests conducted as communicative speaking activities into new lessons other than speaking, I then realize that they get motivated."

Furthermore, after her observation to 5 EFL classes she teaches Sarah states the following criteria related to her students' motivation progress.

a. Low-level achievers get interactive when conducting communicative speaking activities.

b. Almost all students adhere to instructions of classroom management when conducting drama, role playing, games and the like.

c. High-level achievers compete for helping low-level achievers to take part of the communicative speaking activities.

d. After the class time, a number of my students come attend to my office asking me to engage them in leadership roles in communicative speaking activities.

"Successful learning of students is consistently associated with their motivation." (Rashid \& Rana, 2019) Thence, it can be said that EFL instructors can notice criteria of learner's motivation obviously. As most of the interviewees agree that when learners get motivated, their academic achievement, interest in the language, and positive attitude towards EFL are increased.

\section{Is there any connection between communicative speaking activities and learners' motivation?}

Most of the interviewees believe that there is a deep correlation between communicative speaking activities and learners' motivation to learn EFL.

Ghassan claims that communicative speaking activities increase learners' motivation. He states that," Once learners' get involved in communicative speaking activities, their motivation gets to high levels, and as a result, their academic achievement becomes better."

This comment matches what (Wolters, 1999) as cited in (Rashid \& Rana, 2019, P.58) who states that," It is a well-known fact that learners' capability to raise their enthusiasm to participate in overall activities related to academics has been considered as a significant factor to understand their performance and learning."

Rasha, also insists on that there is a close correlation between communicative speaking activities and learners ' motivation to learn EFL. She believes that when learners get motivated, not only their enthusiasm towards learning EFL increases, but also they maintain, in long-term goals, passion to the English language to be learnt in high-academic institutions.

She says, "Many of my learners said that they are aspired the fluency of my speaking during teaching. They state that they want to participate more in communicative speaking activities in order to improve their English language that enables them to study it at universities." 
7.It is said that the Palestinian learners, after 12 years of learning English as a foreign language, lack motivation to learn EFL. How can you, as an EFL teacher, overcome this problem through applying communicative speaking activities?

According to the interviewees' experience, basically low achievement is considered a barrier to learners to be motivated to learn EFL.

For example, Ehssan states that due to various traditional classroom teaching techniques, perspectives of some teachers towards the use of traditional strategies of teaching EFL speaking skills, and many other factors that demotivate EFL learners to learn English language, learners bear in mind that English language as a subject demands sophisticated efforts to be learnt.

Further, Tsuchiya (2004) as cited in Çankaya (2018) found that, among nine demotivation factors he concluded in his study, lack of effective models of speaking and strategies of learning has negative effects on learners motivation. This indicates that learners are frustrated from the idea they have about the difficulty of English language leading them to feel negatively about the language beside the lack of up-to- date teaching strategies of speaking skills.

On the other hand, Reem claims that the family should take the first responsibility for the lack of learners 'motivation to learn English language as they should keep an eye on their children's academic progress, ask them about their interests and attitudes towards learning English and so on. Therefore, the school management should provide EFL teachers with the needed facilities that facilitate conducting communicative activities that foster students' motivation, especially communicative speaking activities.

\section{Conclusion}

The current qualitative study attempts to investigate the impact of communicative speaking activities on learners' motivation to learn EFL from the perspectives of EFL teachers. Conducting semi-structured interviews on 20 EFL instructors from 5 UNRWA schools in Gaza, the findings of the study shows that communicative speaking activities increase learners' motivation to learn EFL especially when the learners engaged effectively in such activities that also, according to the most majority of the interviewees, increase their level of achievement. Also, there is a strong relationship between communicative speaking activities and the increase of EFL learners' motivation to learn EFL.

\subsection{Pedagogical Implications}

The current study sheds the light on many essential implications: Learners' motivation can be fostered by communicative teaching activities in which learners are involved and emerged collaboratively in classroom practices. (Abu Alyan, 2013, P.235) states that, "State-of-the-art teaching techniques and strategies stress the need to encourage and empower learners to participate in class discussions and interactions through positive reinforcement..." As a result, EFL instructors should use various communicative speaking activities to establish a positive classroom atmosphere that reinforces learners to be interested in learning the English language.

On the other hand, EFL instructors are considered the basic column in discovering learners` interests, attitudes and perspectives towards learning EFL; therefore, they can promote learners' motivation through adopting and adapting suitable strategies to deal with them in terms of achieving progress in learning English language.

Furthermore; according to the findings of this study, it is found that there is a close relationship between communicative speaking activities and learners' motivation to learn EFL. So that, if learners are emerged in such activities in a proper way, their achievement will increase and then their motivation to learn EFL will be promoted.

In addition, parents, school management, and EFL instructors should take responsibility for the lack of learners` motivation to learn EFL through keeping track of their academic progress, providing the needed tools and materials that facilitate conducting communicative activities, especially communicative speaking activities, that reinforce learners to learn EFL.

\subsection{Limitation of the Study}

The finding of the study cannot be generalized because of the following reasons:

a. This study targets only five UNRWA schools located at the north of Gaza.

b. Only 10 male and 10 female EFL instructors participate in the study.

c. The number of the semi-structured interviews is small due to the lack of sufficient time of the participants.

d. 4 This study has only one instrument to collect data, so for reliability, another instrument should be included to collect data of the study. 
5.3 Recommendations

Based on the findings of the current study and the theoretical background, it is recommended that:

1. EFL instructors in Gaza should use various communicative activities to motivate learners to learn EFL through the main four skills.

2. Head teachers of the Palestinian public and UNRWA schools should conduct workshops for parents to educate them how to track their children's academic achievements, and how to foster their children's motivation.

3. The ministry of Education should set up training programs for EFL instructors to train them how to foster learners' motivation through communicative activities.

4. Faculties of education in the Palestinian universities should establish programs for pre-service teachers/student teachers to provide them modern educational strategies that can improve learners' motivation.

5. EFL /EFL researchers should conduct more researches to investigate the influence of communicative listening, reading and/or writing activities on learners`motivation to learn EFL.

\section{References}

[1] Abu Alyan,A.(2013).Oral communication problems encountering English major students: Perspectives of learners and teachers in Palestinian EFL university context. Arab World English Journal, 4(3), 226-238.

[2] Aggouni,A.(2015). The role of motivation in enhancing learners`speaking performance in English classrooms. (Published Master dissertation, Mohammed Khider university of Biskra, Algeria, Republic of Algeria). Retrieved from https://pdfs.semanticscholar.org/5cbe/72430ac060345d8dcdbe155d321ea00c455a.pdf

[3] Badroeni,B. (2018).Improving students' motivation in speaking English through active learning strategy. Research and Innovation in Language Learning, 1(2), 76-88. DOI: 1. 76. 10.33603/rill.v1i2.1075

[4] Çankaya,P. (2018).Demotivation factors in foreign language learning. Journal of Foreign Language Education and Technology, $3(1), 1-17$.

[5] Crajcevci,A. \& Shala,A.(2017).Exploring the link between achievement goals, motivation, and parental expectations among university students in Kosovo. Center for Educational Policy Studies Journal, 7(4), 147-164.

[6] Demirzen,M.(1988). Behaviorist theory and language learning. Hacettepe Üniversitesi Eğitim Fakültesi Dergisi, 3(3),135-140.

[7] Eno,M., Kumar,P. and Hamza,S. (2018).Researching EFL motivation: Which skill is learners` favourite motivator?. International Journal of English Research, 4(4), 4-13, ISSN:2455-2186

[8] Gordan,M. \& Krishanan, I. (2014).A review of B.F Skinner's ' Reinforcement theory of motivation'. International Journal of Research in Education Methodology, 5(3), 680-688.

[9] Heng,K. (2014).Communicative language teaching in EFL context: Challenges and suggestions for successful implementation [Published Master dissertation] University of Canberra, Canberra, Australia). Retrieved from https://www.academia.edu/31099049/MA thesis Communicative Language Teaching in E FL Contexts Challenges and suggestions for successful implementation

[10] Johnson,D. (2017).The role of teachers in motivating students to learn . BU Journal of Graduate studies in education, 9(1), 46-49.

[11] Novakova, Z. (2012). How speaking is taught- An overview of approaches to teaching speaking. [PDF file]. Retrieved from https://www.pulib.sk/web/kniznica/elpub/dokument/Strakova3/subor/Novakova.pdf

[12] Ochoa,C. , Cabrera,P. , Quinonez,A., Castillo,L. \& Gonzalez,P.(2016).The effect of communicative activities on EFL learners` motivation: A case of students in the Amazon region of Ecuador. Colomb.Appl. Linguist. J., 18(2), 39-48. DOI: http://dx.doi.org/10.14483/calj.v18n2.10018

[13] Oradee, T. (2012). Developing speaking skills using three communicative activities(Discussion, problem-solving, and role playing). International Journal of Social Science and Humanity,2(6), 533-535.

[14] Pathan,M., Aldersi,Z. and Alsout,E. (2014).Speaking in their language: An overview of major difficulties faced by the Libyan EFL learners in speaking skills. International Journal of English Language and Translation Studies, 2(3), 96-105.

[15] Rashid,S. \& Rana,R.(2019).Relationship between the levels of motivation and learning strategies of prospective teachers at higher education level. Bulletin of Education and Research, 41(1), 57- 66.

[16] Staddon,J.E.R. \& Ceruttie,D.T. (2006). Operant Conditioning. Annu Rev Psychol,2(6), 115-144.

[17] Torky,S.(2006). The effectiveness of a task-based instruction program in developing the English language speaking skills of secondary stage students. (Published Doctoral thesis, Ain Shams university, Cairo, Egypt). Retrieved from https://eric.ed.gov/?id=ED523922

[18] Wijetunge,M.T.N.(2016). Using communicative task-based speaking activities to enhance EFL speaking motivation in undergraduates. International Journal of Humanities, Arts and Social Sciences,2(6), 203-208.

[19] Yulis,P., Antoni,R. and Rasyidah,U. (2016). The correlation between students` motivation and their speaking skill at TH grade in MTS N Rambah. Jurnal Ilmiah Mahasiswa FKIP Prodi Bahasa Inggris, 2(1). 